\title{
The Effect of Executive Compensation on Credit Default Swap Spread
}

\author{
Meizarob ${ }^{1 *}$ and Masripab ${ }^{2}$ \\ ${ }^{1}$ Chatura Consulting, Jakarta, Indonesia \\ ${ }^{2}$ Universitas Pembangunan Nasional Veteran Jakarta, Indonesia
}

\begin{abstract}
Investors have been trying to formulate the optimum composition of executives' compensation which will incentivize the executives to perform better and act in the shareholders' best interests. This study aims to find empirical evidence about the impact of executive compensation on the default risk with the Credit Default Swap (CDS) spread as the proxy, using panel data to test the research model, which combines the analysis of cross-section and time series data. The study is conducted based on 1,416 observations of 177 U.S. companies from 2008-2015. The data are mainly collected from Datastream, Compustat, CRSP, and the US SEC's EDGAR database. The current study provides a contribution by suggesting that executives' compensation will trigger risk-taking behavior. The results of this study reveal, firstly, both equity-based compensation and debt-like compensation induce risk-taking behavior by the executives. Secondly, the correlation between both the form of the compensation and the CDS spread is weakened in a high information asymmetry environment. Lastly, this study finds that a CFO's compensation has more influence on the CDS spread, compared to the other board executives, but this condition only occurs when the compensation is awarded in the form of debt-like compensation. To improve the generalization of the results, a further study may consider expanding the sample into several countries.
\end{abstract}

Keywords: CDS spread; executive compensation; information asymmetry; risk-taking; $\mathrm{CFO}$

JEL classification: G32, G33, G34 


\section{Introduction}

Research into executives' compensation mostly predicts the relationship of pay for performance, based on the agency theory introduced by Jensen and Meckling (1976). The principal delegates some authority to the agent, in order to drive the agent to act on behalf of the principal. Instead of focusing on the shareholders' interests, the agency theory alleges that managers first and foremost act in their own interests. The risk preferences of the agent will be based on the action that will give them the greater benefit. Moreover, due to information asymmetry, the principal cannot be sure that the agent will always act in the principal's best interest. The information asymmetry occurs when a certain group holds information and they do not transmit it to another group. The manager who controls the daily business of the firm has more knowledge and information about the firm, compared to the shareholders. To increase the monitoring, the shareholders will have to pay more. Thus, executives' compensation should be designed to mitigate the agency problem (Jensen and Meckling 1976). Holmstrom (1979) pointed out that the compensation of a firm's management should be linked to the firm's performance; hence, the manager will create value for the shareholders.

Executives' compensation can be awarded in the form of cash, stock, options, pension, and etcetera. Several studies have been conducted to see whether those forms of compensation induce risk-taking. The results of those studies show that balancing compensation and risk-taking remains a challenge. Finance literature mostly focuses on investigating the effect of executive compensation on firm risk. This study aims to add to the literature on the effect of executive compensation on the default risk, along with a recent paper by Bolton, Mehran, and Shapiro (2015). The Credit Default Swap (CDS) spread provides a market estimate of the default risk of the company.

Improving on several prior studies, this study makes a comparison between two forms of compensation: equity-based compensation and debt-like compensation. Devers et al. (2008), Coles, Daniel, and Naveen (2006) and Chen, Steiner, and Whyte (2006) show that equity-based compensation triggers managerial risk-taking. On the other hand, Bolton et al. (2015) focus on CEOs' compensation in the form of deferred compensation and pension benefits because of their debt-like characteristics. They suggest tying executives' compensation to the CDS spread, in order to align the executives' objectives with the shareholders' objectives, in term of risk choices. They find that the percentage of CEOs' incentives, in the form of deferred compensation and pensions, have a negative relationship with the CDS spread (the measure of risk). Their finding is in line with the study by Wei and Yermack (2011) which also found that the revelation of more CEOs' inside debt compensation lowers the CDS spread for these firms. Wei and Yermack (2011) and Edmans and Liu (2010) argue that both deferred pay and pensions are unsecured in the event of a default. As a result, executives with large holdings in deferred pay and pensions are unlikely to undertake risky investment choices. Nevertheless, contrary to previous studies, this research finds that debt-like compensation also has a positive relationship with the CDS spread, like equity-based compensation. A company with a lower 
leverage ratio has room for the executives to take more risks, since the default risk is lower.

This paper also takes into consideration that there might be a condition that may affect the relationship between executive compensation and the CDS spread. Since executive compensation is designed in response to the agency problem, a factor that will affect the agency problem will also affect the alignment of the executives' and shareholders' interests. According to Myers and Majlut (1984), information asymmetry will increase the agency problem and managers will have more chance to act in their own interests. Vallascas and Keasey (2013) and Wintoki et al. (2012) find that the default risk of a bank is increased due to information asymmetry. The information asymmetry allows the management of the firm to act based on the benefits they will get. As a result of information asymmetry, the investors will punish the firm by increasing the cost of acquiring more funds (Bharath et al. 2008). Since the pricing of the CDS is based on the quality of the debt, the increase in the cost of debt will also increase the CDS spread. The above evidence leads us to extend our theory of compensation to propose that information asymmetry moderates the effect of executive compensation on the CDS spread. However, our findings show that instead of strengthening the relationship of compensation and the CDS spread, information asymmetry will weaken the relationship, regardless of the form of the compensation.

This paper extends the prior research by looking into the role of executive management to see which executive manager has more influence over the risk-taking decisions of the company. The executive management could consist of the Chief Executive Officer (CEO), Chief Financial Officer (CFO), Chief Operating Officer (COO), and others. This study finds that a CFO's compensation has slightly more influence on the CDS spread, compared to the other board executives, when the compensation is awarded in a debt-like compensation form. This result is consistent with the findings of Jiang et al. (2010) which state that a CFO has more influence over the financial decision making of the firm compared to the CEO, since it is his/her main responsibility in the firm's financial statement. Chava and Purnanandam (2010) also state that a CFO has more influence when it comes to a debt-related decision.

To sum up, this paper wants to investigate and answer the following main research question:

What is the effect of executive compensation on the CDS spread of a company?

To support the main research question, this paper also examines some sub-questions to gain a greater understanding about the relationship of executive compensation and the CDS spread. The sub-research questions are:

i. What is the best form of compensation to induce less risk-taking?

ii. To what extent does the relationship of executive compensation and the CDS spread's changes have regarding the level of information asymmetry in the industry?

iii. Does a CFO have more influence over the management's risk-taking compared to other members of the executive management?

This research uses panel data to test the research model, which combines the analysis of the cross-section and time se- 
ries data. The panel data approach used in this paper is the Fixed Effect Model (FEM) for all the models testing the hypotheses. The study is conducted based on 1,416 observations of 177 U.S. companies from 2008-2015. The data are mainly collected from Datastream, Compustat, the Center for Research in Security Prices (CRSP), and the US SEC's EDGAR database.

The results of this study can be beneficial for the shareholders and executives when viewing risk-taking incentives. It can help the shareholders to understand the conditions that will motivate the executives to take more risks and help them in setting a control to manage the risk taken by the executives. On the other hand, it helps the executives to be more aware of the effects of their risk-taking behavior.

The remainder of this paper is structured as follows. In the next section, a literature review regarding the recent studies and development of the CDS spread, executive compensation, and information asymmetry is provided and the hypotheses development is built. In the third section, the methodology of this paper is described. The fourth section explains the results of the analysis. Finally, the last section provides a summary of the current findings and is also complemented by the current study's limitations and prospective steps for further research.

\section{Literature Review}

\section{CDS Spread}

This paper uses the CDS spread as the proxy of the default risk, since it is widely considered to be an excellent indicator of the markets' perception of a firm's default risk (Bolton et. al. 2015). CDS is an insur- ance contract to transfer the credit exposure between two or more parties. The premium paid by the CDS holder is in line with the riskiness of the firm's credit; the higher the risk, the higher the premium (Hull et al. 2004). The amount that should be paid by the CDS buyer is known as the CDS spread. If the bond issuer fails to pay its debt, the seller of the CDS has to buy back the defaulted bond from the buyer at its par value (Longstaff et al. 2005). CDS does not require the protection's buyer to hold the bonds of the reference entity. Thus, an investor can use CDS to speculate on the default or credit downgrades of the bonds (White 2014). The premium of the CDS spread depends on the credit quality of the issuer and on the maturity of the bond. It also prices the credit risk of the underlying firm by using the quality ratings of a number of financial ratios (Bodie et al. 2011). These ratings reflect the overall credit risk of the firm and the risk of them defaulting on their obligation. A higher risk of default will result in a lower credit rating for the firm. The bondholder will ask for a higher yield to compensate the higher risk of default that they bear. It will also lead to a higher premium for the CDS.

\section{Executive Compensation and CDS Spread}

Even though the bond issuers do not play a direct role in a CDS contract, as the issuer of the underlying securities, they affect the CDS spread. Any actions by the bond issuer that will increase the probability of a default of the bonds will also increase the premium paid by the CDS buyer. The executive management of the company, which is the bond issuer, has a role in driving the risk taken by the firm. 
Through his research in 1979, Holmstrom shows that the firm should tie up the managers' compensation with the firm's performance. Therefore, it can solve the agency problem and push the managers to act in the shareholders' interest. However, according to Bolton et al. (2015), structuring the executive compensation to maximize shareholder value will encourage them to take excessive risks. This section explains the relationship between executive compensation and the CDS spread, which is used to formulate the hypotheses.

\section{Pay-performance Relationship}

The idea underlining pay for performance is based on the agency theory (Amzaleg et. al. 2014). Based on this theory, compensation plans are designed to balance the self-interest of the executives with their shareholders' interests. Directly monitoring the executives' behavior is difficult. Many scholars suggest aligning the risk preferences of the executives and shareholders by granting the executives equity-based compensation, which is assumed to discourage risk aversion (Devers et al. 2008). This equity-based compensation is the sum of any option-based compensation and the restricted shares owned by the executives. By tying up the executives' compensation with the firm's performance, the executives will have to work harder to obtain their share of the gains of the company. Other studies by Coles, Daniel, and Naveen (2006) and Chen, Steiner, and Whyte (2006) show that aligning the executives' compensation to performance has another impact. They use equity-based compensation as the proxy for executive compensation. Since their wealth is sensitive to the firm's stock return, the executives will be more eager to take a risk which will increase the firm's risk. Increasing firm risk could increase the probability of default, so this paper hypothesizes that the CDS spread will also increase. The hypothesis is as follows:

\section{Hypothesis 1a: Equity-based compensation has a positive impact on the CDS spread of a firm.}

A recent study by Bolton et. al. (2015) focuses on deferred compensation and pension benefits, instead of equity-based compensation, to reduce risky behavior. Both deferred compensation and pension benefits have a debt characteristic, since they are unsecured future claims. Jensen and Meckling (1976) speculate that to attenuate the stockholder-bondholder conflicts, the executives should be granted equal proportions of debt-like compensation and equity-based compensation. Thus, the executives will not be purely equity-aligned (Edmans and Liu 2010). Other studies by Wei and Yermack (2011) and Edmans and Liu (2010) also find that debt-like compensation reduces risk-taking. After the financial crisis of 2007-2008, the greater use of deferred compensation for executive management has been advocated by a lot of parties (Wei and Yermack 2011). The recommendation arose due to the belief that equity-based compensation caused excessive risk-taking. In the large majority of firms, the debt-like compensation exposes the executives to the same default risks that are borne by outside creditors. Thus, by awarding the executives a debt-like compensation, they will be more careful in their actions, so as not to increase the default risk of the firm. Aligned with these studies, this paper develops a hypothesis, as follows: Hypothesis 1b: Debt-like compensation has a negative impact on the CDS spread of a firm. 


\section{Information Asymmetry}

Research by Acharya and Johnson (2007) and Chiappori (2000) show that information asymmetry causes the insurance premium to increase in equilibrium. Acharya and Johnson (2007) studied the insurance of credit default (the proxy is CDS) while Chiappori (2000) studied the information asymmetry in car insurance. The driver in this conclusion is the presence of "common values" which is the link between the agents' hidden information and the other party's payoff (Chiappori 2000). For example, in the market for "lemons", the buyer's payoff depends on the quality of the car, which is only known by the seller. Similarly, the CDS buyer should pay an amount which is dependent on the quality of the underlying asset, which is mostly known and driven by the insider of the firm. Bharath et al. (2008) argue that asymmetric information is an important determinant of capital structure decisions. They argue that if managers have more information about the firm's value than the rest of the market, they will be penalized by the market. The cost of acquiring more funds will increase since it is incorporated with the risk of asymmetric information held by the investor. The increase in the cost of debt will cause an increase in the CDS spread as well, since the pricing of the CDS is also based on the quality of the debt as the underlying assets.

Based on the above arguments, this paper predicts that information asymmetry will strengthen the relationships of equity-based compensation, as discussed in Hypothesis 1a. When the executives are granted an equity-based compensation, they will be induced to take more risks. This paper hypothesizes that debt-like compensation has a negative impact on the CDS spread, while the information asymmetry could increase the default risk of the firm. Thus, the information asymmetry will neutralize the relationship between debt-like compensation and the CDS spread. However, when they are granted a debt-like compensation, they will be more reluctant to take the risk. The hypotheses are as below: Hypothesis 2a: Information asymmetry strengthens the relationship of equity-based compensation and the CDS spread.

Hypothesis 2b: Information asymmetry weakens the relationship of debtlike compensation and the CDS spread.

\section{Chief Financial Officer vs Other Board Executives}

The executive management consists of several people. One member could have greater authority than the other members. A study by Duong and Evans (2015) reveals that compensation is not linked to performance at the CFO-specific level. In contrast to the incentive alignment approach, the CFOs receive more non-cash compensation even though the quality of reporting is lower. On the other hand, Jiang et al. (2010) investigated the influence of the Chief Executive Officer (CEO) and Chief Financial Officer (CFO) on earnings management. They find that the $\mathrm{CFO}$ has a greater role in earnings management, and the firm's likelihood of beating any forecasts by analysts is also more sensitive to the CFO's incentives, compared to those of a CEO. The reason is that the CFOs' main responsibility is the firms' financial reporting. According to Chava and Purnanandam (2010), the incentives of a firm's key management are related to cor- 
porate risk-taking. The risk preference of the CEO affects the leverage and cash-holding policies. However, when it comes to debt maturity's structure and accrual decisions, the CFO's risk preferences have more impact on the decisions taken. This evidence supports the Securities and Exchange Commission's (SEC) disclosure requirement on CFOs' compensation.

In 2006, the Securities and Exchange Commission (SEC) amended its disclosure regulations on executive compensation by requiring firms to disclose their CFOs' compensation. The SEC stated that "compensation of the principal financial officer is important to shareholders because along with the principal executive officer, the principal financial officer provides the certifications required with the company's periodic reports and has important responsibility for the fair presentation of the company's financial statements and financial information" (Securities and Exchange Commission 2006: 117). Thus, when analyzing the effect of executives' compensation on the CDS spread; this paper assumes that the CFO will have a greater impact than the other executives on the board.

Hypothesis 3a: The CFO's equity-based compensation has a stronger effect on the CDS spread than the other board executives' equitybased compensation.

Hypothesis 3b: The CFO's debt-like compensation has a stronger effect on the CDS spread than the other board executives' debt-like compensation.

\section{Methods}

\section{Data Collection}

The population of the data in this research is U.S. based companies, which has the most comprehensive database available. The final dataset consists of the CDS spread, equity-based compensation, debtlike compensation, and stock data. The period starts from 2008 until 2015 since the CDS spreads' data are available on Thomson Reuters Datastream from December 2007. However, the compensations' data starts from 2007, since lagged variables are used. The sample selection requires the companies to have data available on Datastream, Compustat, the Center for Research in Security Prices (CRSP), and the U.S. SEC's EDGAR database to construct the variables. As a result, there are 117 companies that met the requirements. Besides the variable mentioned in the hypotheses, this research also uses ownership concentration and firm characteristics as control variables.

\section{Variables}

\section{CDS Spread}

The CDS spread data is retrieved from Datastream which has a daily interval. The spread is expressed in basis points of the notional amount of the contract (Pires et al. 2015). The CDS spread data are available for ten different maturities varying from one to ten years. This research uses the average daily spread over the whole year of a five-year maturity contract. The 
CDS of a five-year maturity contract is the type of CDS that is usually embedded in a firms' most widely traded contract (Bolton et. al. 2015). According to Blanco et al. (2005), it is also the most liquid spread amongst the available CDS spreads. Senior CDS spreads are used since they offer better data coverage than subordinated (Chiaramonte and Casu 2013).

\section{Equity-Based Compensation}

This paper uses the average equitybased compensation of multiple executives. The equity-based compensation consists of the option and restricted shares awarded to the executives. The restricted shares' value is retrieved from Compustat. The options are valued by using the option pricing model from Black, Scholes and Merton, as described in Core and Guay (2002). This model is widely used because of its riskneutral feature which is achieved through its dynamic hedging paradigm (Corrado 2009).

The amounts of granted options and previously granted options are retrieved from Compustat. The inputs used to calculate the options' value are stock price, volatility, dividend yield, risk-free rate, exercise price, and time-to-maturity. The stock price is available on CRSP. The stock price which is used to value the restricted stock and options is the share price on 31 December each year. The expected stock return volatility and expected dividend yield are estimated using Compustat and CRSP data. The dividend yield is calculated by dividing the dividend per share granted in that year with share price as of 31 December. The volatility is the variance of the daily stock returns over the whole year. The risk-free rate is based on the US Government Treasury Yield correspond to the option's time-to-maturity. The exercise price and time-to-maturity are retrieved from the company's proxy statement DEF$14 \mathrm{~A}$ which is available on EDGAR. To mitigate the possibility of simultaneity concerns, the equity-based compensation is matched to the CDS spread data of a year later.

\section{Debt-Like Compensation}

The debt-like compensation consists of deferred compensation and pension benefits. This paper uses the average value of the debt-like compensation for all executives, which is available on Compustat Execucomp.

\section{Information Asymmetry}

The share price explains a significant part of the information asymmetry (Boujelbene and Besbes 2012; Attig et al. 2006). It represents the unobservable minimum cost borne by the investors (Boujelbene and Besbes 2012). The share price is a proxy for the unobservable minimum cost of detention of the market makers, and it influences the variability of the shareholders' return. Thus, this research uses a dummy variable as the proxy of information asymmetry: one (1) if the difference between the highest bid and the lowest ask price during the year is higher than the average spread within the industry, otherwise, the dummy variable is zero $(0)$. The bid and ask price are retrieved from Compustat.

\section{Ownership Concentration}

The ownership concentration is included in this research as a control variable. Paligorova (2010) argues that ownership structure affects the ability of shareholders to influence the corporate risk-taking. When the ownership is concentrated with 
Table 1. Firm Characteristics

\section{Firm Characteristics Measurement}

\begin{tabular}{ll}
\hline ROA & Net income divided by lagged total assets \\
Leverage ratio & Total liabilities divided by total assets \\
Cash holding ratio & Cash holdings divided by total assets \\
Firm risk & The logarithm of the daily stock price's variance per month \\
Tobin's Q ratio & Total market value of the firm divided by total assets
\end{tabular}

just a few shareholders, those shareholders will have more incentives to gather information and monitor the firm to maximize their profit. Laeven and Levine (2009) find that majority shareholders tend to accept a higher level of risk. Hammami and Boubaker (2015) also confirm this finding by studying the ownership structure of banks and the relation to risk-taking. They find that the risk-taking behavior will differ depending on the degree of ownership concentration. The proxy of ownership concentration is the ownership percentage of the largest shareholders. The shareholders' data is retrieved from the company's proxy statement available on EDGAR.

\section{Firm Characteristics}

The firm characteristics which are used as control variables in this paper are Return on Assets (ROA), leverage ratio, cash holding ratio, firm risk, and Tobin's $Q$ ratio. These firm characteristics are widely used as control variables since empirical research has found that they determine the tendency of a firm to take risks and are similar to those previous studies of Coles et al. (2006) and Aunon-Nerin et al. (2002). The data to construct ROA, lever- age ratio, cash holding ratio, firm risk, and Tobin's $Q$ ratio are retrieved from Compustat and calculated as shown in Table 1.

\section{Research Model}

This research uses three equation models to answer the research questions which are captured in the hypotheses 1,2 , and 3. The regression in this study is performed using Stata. The equation models in this research are as follows:

\section{Model 1}

$$
\begin{aligned}
\mathrm{CDS}_{\mathrm{it}}= & \alpha_{1}+\alpha_{2} \mathrm{EBC}_{\mathrm{it}}+\alpha_{3} \mathrm{DLC}_{\mathrm{it}}+\alpha_{4} \mathrm{IA}_{\mathrm{it}} \\
& +\alpha_{7-12} \text { Controls }_{\mathrm{it}}+\varepsilon_{\mathrm{t}}
\end{aligned}
$$

\section{Model 2}

$$
\begin{aligned}
\mathrm{CDS}_{\mathrm{it}}= & \alpha_{1}+\alpha_{2} \mathrm{EBC}_{\mathrm{it}}+\alpha_{3} \mathrm{DLC}_{\mathrm{it}}+\alpha_{4} \mathrm{IA}_{\mathrm{it}} \\
& +\alpha_{5} \mathrm{IA} * \mathrm{EBC}_{\mathrm{it}}+\alpha_{6} \mathrm{IA}^{*} \mathrm{DLC}_{\mathrm{it}}+ \\
& \alpha_{7-12} \text { Controls }_{\mathrm{it}}+\varepsilon_{\mathrm{t}}
\end{aligned}
$$

\section{Model 3}

$$
\begin{aligned}
\mathrm{CDS}_{\mathrm{it}}= & \alpha_{1}+\alpha_{2} \mathrm{CFO} \mathrm{EBC}_{\mathrm{it}}+\alpha_{3} \mathrm{CFO} \\
& \mathrm{DLC}_{\mathrm{it}}+\alpha_{4} \mathrm{OBEEBC}_{\mathrm{it}}+\alpha_{5} \mathrm{OBE} \\
& \mathrm{DLC}_{\mathrm{it}}+\alpha_{6} \mathrm{IA}_{\mathrm{it}}+\alpha_{7-12} \text { Controls }_{\mathrm{it}}+ \\
& \varepsilon_{\mathrm{t}}
\end{aligned}
$$

where CDS is the average of the daily credit default swap spread, EBC is the average 
equity-based compensation for all the executive management, DLC is the average debt-like compensation of all the executive management, IA is the dummy variable for information asymmetry, IA*EBC is the interaction between information asymmetry and equity-based compensation, IA*DLC is the interaction between information asymmetry and debt-like compensation, CFO EBC is the CFO's equitybased compensation, CFO DLC is the CFO's debt-like compensation, OBE EBC is the average of the other board executives' equity-based compensation, OBE DLC is the average of the other board executives' debt-like compensation and the control variables of ownership concentration, ROA, leverage ratio, cash holding ratio, firm risk, and Tobin's $Q$ ratio.

\section{Data Analysis and Discussion}

\section{Descriptive}

Table 2 provides the distribution of variables used in all the regression models.

\section{Table 2. Descriptive Statistics}

\begin{tabular}{ccccccc}
\hline Variable & $\mathbf{N}$ & Mean & Min. & Median & Max. & Skew \\
\hline CDS & 1,416 & 223.95 & 12.84 & 130.48 & $1,878.17$ & 3.38 \\
EBC & 1,416 & 13,727 & 19.51 & 7,448 & 415,959 & -0.43 \\
DLC & 1,416 & 5,185 & 0.00 & 2,907 & 54,206 & -1.80 \\
IA & 1,416 & 0.46 & 0.00 & 0.00 & 1.00 & 0.16 \\
CFO EBC & 1,416 & 7,780 & 0.00 & 4,224 & 171,982 & -1.92 \\
CFO DLC & 1,416 & 2,904 & 0.00 & 1,149 & 45,631 & -1.05 \\
OBE EBC & 1,416 & 15,152 & 0.00 & 8,083 & 476,954 & -0.79 \\
OBE DLC & 1,416 & 5,805 & 0.00 & 3,174 & 62,812 & -1.79 \\
LEV & 1,416 & 0.28 & 0.00 & 0.25 & 1.51 & 1.56 \\
OWN & 1,416 & 11.78 & 3.90 & 9.40 & 51.14 & 3.30 \\
CHR & 1,416 & 0.06 & 0.00 & 0.04 & 0.55 & 2.11 \\
FR & 1,416 & 0.40 & 0.10 & 0.31 & 2.65 & 2.33 \\
ROA & 1,416 & 0.71 & -0.06 & 0.59 & 3.77 & 1.70 \\
TQ & 1,416 & 0.81 & 0.01 & 0.64 & 5.99 & 2.07 \\
\hline
\end{tabular}

\section{Description:}

$\mathrm{CDS}=\mathrm{CDS}$ Spread $; \mathrm{EBC}=$ Equity-based Compensation; $\mathrm{DLC}=$ Debt-like Compensation $; \mathrm{IA}=$ Information Asymmetry; LEV = Leverage; OWN = Ownership Structure; CHR = Cash Holding Ratio; FR = Firm Risk; ROA = Return of Asset; TQ = Tobin's Q; CFO EBC = CFO's Equity-based Compensation; CFO DLC = CFO's Debt-like Compensation; OBE EBC = Other Board Executives' Equity-based Compensation; OBE DLC $=$ Other Board Executives' Debt-like Compensation. The CDS is expressed as a basis point. The data used in this research are nominated in US dollars. The EBC, DLC, CFO EBC, CFO DLC, OBE EBC, OBE DLC are stated in thousands of US dollars. 
The minimum and mean values of the CDS spread are much lower than its maximum value. Thus, the data is widely spread with a skewness value of 3.38 and the skewed distribution of this variable tends to the lefthand direction.

To begin with the executive compensation data, the executive management received more compensation in the form of equity-based compensation than debt-like compensation. On average, the executives received USD 13,727 thousand equitybased compensation and US 5,185 thousand debt-like compensation. The CFO received less compensation, compared to the other board executives, for both forms of compensation.

The information asymmetry is represented with a dummy variable with the value of one (1) for a high information asymmetry firm and the value of zero (0) for less information asymmetry. On average, 46 percent of the sample's firms have a high information asymmetry and 54 percent of the observations are firms with a low information asymmetry.

The distribution of ownership concentration in the sample is widely spread. The sample consists of firms which are highly concentrated, with one firm's largest shareholder owning 51.14 percent of the firm's shares, while another firm's largest shareholder owns only 3.9 percent of the firm's shares. The sample selection excludes the firms which do not disclose their largest shareholder.

Continuing to the variables of firm characteristics, the variable ROA has a negative minimum value. This is because bad performers are not excluded from the sample. The leverage ratio and cash holding ratio have a minimum value of zero (0), this is because the company has remaining leverage and cash worth less than one million, and the data available on Compustat is in millions of USD.

\section{Compensation on CDS Spread}

The regression results for Model 1 show that the equation model has a value for the F-statistic of 147.93, with a probability (F-statistic) of 0.000 . These results show that Model 1 has a significant probability at the 1 percent level. It explains that all of the independent variables tested in Model 1 significantly affect the CDS spread, as the dependent variable, simultaneously, but the effects are very weak. Executive compensation is the main explanatory variable in this study. Both equity-based compensation and debt-like compensation significantly affect the CDS spread. The equity-based compensation has a coefficient of 0.0000305 and a p-value of 0.001 . This means that the equity-based compensation variable has a positive effect on the CDS spread at the 1 percent significance level, although the small coefficient indicates that the CDS spread has other bigger determinant factors. The result of this test aligns with the previous studies by Devers et al. (2008), Coles et al. (2006), and Chen et al. (2006) which concluded that by awarding equity-based compensation to the executive management, they will be more willing to take a risk, which can cause the default risk of the firm, which is measured by the CDS spread, to increase.

The variable debt-like compensation has a coefficient of 0.0016294 and a p-value of 0.000 . This suggests that the debt-based compensation has a significant positive effect on the CDS spread. Instead of neutralizing the willingness of the executive to take 
Table 3. Regression Result of Model 1

\begin{tabular}{|c|c|c|c|c|}
\hline \multirow{2}{*}{ Variable } & \multirow{2}{*}{ Expectation } & \multicolumn{3}{|c|}{ CDS } \\
\hline & & Coeff & Prob & \\
\hline $\mathrm{C}$ & & 0.0045589 & 0.000 & \\
\hline $\mathrm{EBC}$ & + & 0.0000305 & 0.000 & $* * *$ \\
\hline DLC & - & 0.0016294 & 0.000 & $* * *$ \\
\hline IA & + & -0.0066792 & 0.000 & $* * *$ \\
\hline LEV & + & 0.0151804 & 0.000 & $* * *$ \\
\hline OWN & + & 0.000249 & 0.000 & $* * *$ \\
\hline CHR & - & -0.0067949 & 0.121 & \\
\hline FR & + & 0.0397769 & 0.000 & $* * *$ \\
\hline $\mathrm{ROA}$ & - & -0.0001255 & 0.012 & $* *$ \\
\hline TQ & - & -0.0011197 & 0.227 & \\
\hline \multicolumn{2}{|c|}{ Adj. R-squared } & \multicolumn{2}{|c|}{0.3038} & \\
\hline \multicolumn{2}{|c|}{ F-statistic } & \multicolumn{2}{|c|}{147.93} & \\
\hline \multicolumn{2}{|c|}{ Prob. (F-statistic) } & \multicolumn{2}{|c|}{0.0000} & \\
\hline
\end{tabular}

$* * *$ significant at 1 percent level; $* *$ significant at 5 percent level

\section{Description:}

$\mathrm{EBC}=$ Equity-based Compensation; DLC $=$ Debt-like Compensation; IA = Information Asymmetry; LEV = Leverage; OWN = Ownership Structure; CHR = Cash Holding Ratio; FR = Firm Risk; ROA = Return of Asset; $\mathrm{TQ}=$ Tobin's $\mathrm{Q}$.

risks, debt-like compensation triggers the executives to take risks. Bolton et. al. (2015) and Wei and Yermack (2011) find that debtlike compensation is associated with lower risk-taking. The sample period of their studies was before the financial crisis of 2008 . Tung and Wang (2011) and Bekkum (2014) compare the impact of debt-like compensation and risk-taking before and after the crisis. Before the crisis, their studies reveal that the debt-like compensation lowers risktaking. However, after the crisis, the result is the opposite. This different impact is caused by the lower leverage ratio after the financial crisis. It gives room for the executives to take more risks since the default risk is lower. Both equity-based compensation and debt-like compensation significantly affect the CDS spread. The coefficient of debt-like compensation is bigger than the coefficient of equity-based compensation which means the debt-like compensation has a higher impact on the CDS spread. This should form part of the shareholders' considerations when structuring the executives' compensation. 
Information Asymmetry, Compensation, and CDS Spread

The regression results for Model 2 show that the model equation's F-statistic has a value of $11,674.58$ with a probability (F-statistic) of 0.000 . The results indicate that Model 2 in this study has a significant probability at the 1 percent level. It explains that all of the independent variables in Model 2 significantly affect the CDS spread, as the dependent variable. The value of the adjusted $\mathrm{R}$-squared is 0.3074 . The coefficient of the interaction between information asymmetry with equity-based compensa- tion is negative, but significant. Instead of strengthening the relationship of equitybased compensation and the CDS spread, information asymmetry will weaken the relationship. The reason is that the hidden information known by the executives has already been used, and reflected in their risk-taking decision which is captured in Model 1. Thus, the information asymmetry does not add incentives for the risk-taking behavior of the executives.

The interaction between information asymmetry with debt-like compensation has a negative coefficient and a significance below 1 percent. This means that informa-

\section{Table 4. Regression Result of Model 2}

\begin{tabular}{lccc}
\hline \multirow{2}{*}{ Variable } & \multirow{2}{*}{ Expectation } & \multicolumn{2}{c}{ CDS } \\
\cline { 3 - 4 } & & Coeff & Prob \\
\hline C & & 0.0044676 & 0.130 \\
EBC & + & 0.000033 & 0.000 \\
DLC & - & 0.0020352 & 0.000 \\
IA & + & -0.0028255 & 0.057 \\
IA*EBC & + & -0.0103837 & 0.000 \\
IA*DLC & - & -0.0125916 & 0.000 \\
LEV & + & 0.0143249 & 0.000 \\
OWN & + & 0.0002625 & 0.000 \\
CHR & - & -0.0048796 & 0.180 \\
FR & + & 0.039787 & 0.000 \\
ROA & - & -0.0001274 & 0.011 \\
TQ & - & -0.001282 & 0.187 \\
Adj. R-squared & \multicolumn{3}{c}{0.3074} \\
F-statistic & \multicolumn{3}{c}{$11,674.58$} \\
Prob. (F-statistic) & \multicolumn{3}{c}{$0 / 0000$} \\
\hline
\end{tabular}

\section{Description:}

$\mathrm{EBC}=$ Equity-based Compensation; DLC = Debt-like Compensation; $\mathrm{IA}=$ Information Asymmetry; IA*EBC = Interaction between information asymmetry and equity-based compensation; IA* DLC $=$ Interaction between information asymmetry and debt like compensation; LEV = Leverage; OWN= Ownership Structure; $\mathrm{CHR}=$ Cash Holding Ratio; FR = Firm Risk; ROA = Return of Asset; TQ = Tobin's Q. 
tion asymmetry weakens the relationships of debt-like based compensation and the CDS spread. This result supports the previous study of Vallascas and Keasey (2013) and Wintoki et al. (2012). They find that the default risk of a firm is increased due to information asymmetry and, based on studies by Bolton et. al. (2015), Wei and Yermack (2011), and Edmans and Liu (2010), debt-like compensation reduces risk-taking by the executives. Since they have different directions, information asymmetry increases the risk while debt-like compensation reduces the risk, the information asymmetry will neutralize the rela- tionship of debt-like compensation and the CDS spread.

\section{CFO on CDS Spread}

The model has the F-statistic of 60.00 with a probability (F-statistic) of 0.000 which is much smaller than 1 percent. This suggests that the independent variables significantly affect the dependent variable simultaneously. The adjusted R-squared is 0.3331 or 33 percent. It shows that the CDS spread can be explained by $\mathrm{CFO} O \mathrm{OBC}$, CFO DBC, OEB OBC, OEB DBC, information asymmetry, leverage, ownership,

Table 5. Regression Result of Model 3

\begin{tabular}{|c|c|c|c|c|c|}
\hline \multirow{2}{*}{ Variable } & \multirow{2}{*}{ Expectation } & \multicolumn{2}{|c|}{ CDS } & & \multirow{2}{*}{ Description } \\
\hline & & Coeff. & Prob. & & \\
\hline $\mathrm{C}$ & & 0.0195844 & 0.120 & & \\
\hline CFO EBC & + & 0.0009122 & 0.105 & & $\begin{array}{l}\text { CFO's Equity-based } \\
\text { Compensation }\end{array}$ \\
\hline CFO DLC & - & 0.0019625 & 0.020 & $* *$ & CFO's Debt-like Compensation \\
\hline OBE EBC & + & -0.0001018 & 0.000 & $* * *$ & $\begin{array}{l}\text { Other board executives' Equity- } \\
\text { based Compensation }\end{array}$ \\
\hline OBE DLC & - & -0.0019013 & 0.000 & $* * *$ & $\begin{array}{l}\text { Other board executives' Debt-like } \\
\text { Compensation }\end{array}$ \\
\hline IA & + & -0.0056141 & 0.000 & $* * *$ & Information Asymmetry \\
\hline LEV & + & 0.0122068 & 0.001 & $* *$ & Leverage \\
\hline OWN & + & 0.0002389 & 0.000 & $* * *$ & Ownership Structure \\
\hline $\mathrm{CHR}$ & - & -0.0142514 & 0.010 & $* *$ & Cash Holding Ratio \\
\hline FR & + & 0.0373153 & 0.000 & $* * *$ & Firm Risk \\
\hline $\mathrm{ROA}$ & - & -0.0000845 & 0.010 & $* *$ & Return of Asset \\
\hline TQ & - & -0.0000982 & 0.466 & & Tobin’s Q \\
\hline \multicolumn{2}{|c|}{ Adj. R-squared } & \multicolumn{2}{|c|}{0.3331} & & \\
\hline \multicolumn{2}{|c|}{ F-statistic } & \multicolumn{2}{|c|}{60.00} & & \\
\hline \multicolumn{2}{|c|}{ Prob. (F-statistic) } & \multicolumn{2}{|c|}{0} & & \\
\hline
\end{tabular}

$* * *$ significant at 1 percent level; ** significant at 5 percent level. 
cash holding ratio, firm risk, ROA, and Tobin's $Q$ by 33 percent, and the remaining 67 percent is explained by other variables that are not addressed in this study.

This paper also compares the effect of the CFOs' and other executives' compensation on the CDS spread. The CFOs' equity-based compensation has a positive coefficient but does not significantly affect the CDS spread, while the other board executives' equity-based compensation significantly affects the CDS spread. This is probably due to the CFO receiving less equitybased compensation compared to the other board executives. While, on average, the CFO received USD 7,780 million equitybased compensation, other board executives, on average, received USD 15,152 million equity-based compensation each. However, when the CFO is excluded from the executives' equity-based compensation, this type of compensation has a negative impact on the CDS spread. It can be seen from the negative coefficient of the other board executives' equity-based compensation which is -0.0001018 . While the CFO's equity-based compensation has no effect on CDS spread, the equity-based compensation could reduce the risk-taking behavior by the other board executives. Duong and Evans (2015) find that a CFO's compensation is not related to his/her performance. When the CFO delivers lower quality reporting, they receive a higher noncash compensation. It supports the finding of this paper. The CFO will not be triggered to take more risk since his/her compensation is not related to performance.

Both a CFO's debt-like compensation and the other board executives' debt-like compensation significantly affect the CDS spread and this is comparable at a level of significance of 5 percent. The coefficients of debt-like compensation for the CFO and other board executives are 0.0019625 and 0.0019013 , respectively. The coefficient for the CFO is slightly higher than for the other board executives. It means the CFO's debt-like compensation has a bigger impact on the CDS spread, compared to that of the other board executives. Hence, Hypothesis $3 \mathrm{~b}$ is not rejected. However, the CFO's debt-like compensation has a positive coefficient which aligns with the regression result in Model 1, while the coefficient of the other board executives' debt-like compensation is negative, which supports the previous studies by Bolton et al. (2015), Wei and Yermack (2011), and Edmans and Liu (2010).

\section{Control Variable Analysis}

All the control variables in this paper affect the CDS spread, and meet the expectations, except the Tobin's $Q$ and cash holding ratio. Except for the Tobin's $Q$ and cash holding ratio, the results align with studies by Coles et al. (2006). A study by Aunon-Nerin et al. (2002) reveals that market capitalization has a significantly negative relationship with the CDS spread, but only for highly rated companies because in this case, the debt holder has greater trust that the company will be able to pay its obligation. This research uses Tobin's Q, which is the percentage of market capitalization on total assets. This research does not categorize the company based on their bond rating. Since the sample might consist of highly rated and low rated companies, the effect of ratio of Tobin's $Q$ on the CDS spread does not seem to matter. In all of the models, the cash holding ratio has a negative coefficient, supporting the simple intuition that higher cash reserves make corporate debt safer. However, the 
cash holding ratio does not significantly affect the CDS spread in Model 1 and Model 2, but it significantly affects the CDS spread in Model 3. A possible explanation could be because of endogenous adjustments in the cash holdings of the firms, which will be used for investments instead of keeping it as free cash (Léautier 2007).

\section{Conclusions}

This study aims to give a better understanding of the effect of executive compensation on the CDS spread, as a proxy of the credit risk of the company. The relationship between compensation and risk remains a challenge, since a lot of financial scandals started with a demand for higher compensation. This study focuses on the explanatory variable executive compensation and the dependent variable CDS spread. Both forms of equity-based compensation and debt-like compensation will induce risk-taking behavior by the executives, reflected in a higher CDS spread. However, debt-like compensation, as the driver of risk-taking, has more impact compared to equity-based compensation. In the high information asymmetry environment, the relationship between both forms of compensation and CDS spread will be weakened. Assuming that the executives will use all of the information that they have about the firm, information asymmetry will not give an additional chance for the executive to take more risks.
This study also looks further, into whether the CFO has more influence on the risk taken by the firm compared to the other board executives. First, these findings reveal that the CFO's compensation has slightly more influence on the CDS spread, compared to the other board executives, but this condition only occurs when the compensation is awarded in debt-like compensation form. Another finding reveals that the CFO is more willing to take risks, compared to other board executives, especially when the compensation is given in the form of debt-like compensation. When the CFO's compensation is excluded from the executives' compensation, the compensation has a negative relationship with risk, which is measured by the CDS spread. However, this study has several limitations. Firstly, this study uses the longest time series, based on the available data, but the sample is only from one country. A future study may consider expanding the sample into several countries. Hence, it can improve the generalization of the results. Secondly, the CDS spread data has a tendency for dispersion. Before the outlier treatment performed in this study, the distribution of the CDS spread has a heavy right tail and strong skewness. Further research should attempt to use another form of regression, such as quantile regressions, to give a better description of the entire conditional distribution of the CDS spread. 


\section{References}

Acharya, V. V., and T. C. Johnson. 2007. Insider trading in credit derivatives. Journal of Financial Economics 84: 110-141.

Amzaleg, Y., O. Azar, U. Ben-Zion, and A. Rosenfeld. 2014. CEO control, corporate performance and pay-performance sensitivity. Journal of Economic Behaviour and Organization 106: $166-174$.

Attig, N., W. M. Fong, Y. Gadhoum, and L. H. P. Lang. 2006. Effects of large shareholding on information asymmetry and stock liquidity. Journal of Banking and Finance 30: 2875-2892.

Aunon-Nerin, D., D. Cossin, T. Hricko, and Z. Huang. 2002. Exploring for the determinants of credit risk in credit default swap transaction data: is fixed-income markets' information sufficient to evaluate credit risk? FAME Research Paper 65.

Bekkum, S. V. 2014. Inside debt and bank risk. Journal of Financial and Quantitative Analysis.

Bharath, S., P. Pasquariello, and G. Wu. 2008. Does asymmetric information drive capital structure decisions? The Revierw of Financial Studies 22 (8).

Blanco, R., S. Brenan, and I. W. Marsh. 2005. An empirical analysis of the dynamic relationship between investment grade bonds and credit default swaps. The Journal of Finance 60 (5): 2255-2281.

Bodie, Z., A. Kane, and A. J. Marcus. 2011. Investments and Portfolio Management (9 ${ }^{\text {th }}$ ed.). Singapore: McGraw-Hill.

Bolton, P., H. Mehran, and J. Shapiro. 2015. Executive compensation and risk-taking. Review of Finance 19: 2139-2181.

Boujelbene, Y., and L. Besbes. 2012. Determinants of information asymmetry between managers and investors: a study on panel data. IBIMA Business Review: 1-11.

Chava, S., and A. Purnanandam. 2010. Is default risk negatively related to stock returns? Review of Financial Studies 23: 2523-2559.

Chen, C., T. Steiner, and A. Whyte. 2006. Does stock option-based executive compensation induce risk-taking? An analysis of the banking industry. Journal of Banking and Finance 30: 915-945.

Chiappori, P. 2000. Econometric Models of Insurance under Asymmetric Information: 365-93. Handbook of Insurance of Kluwer Academic Publishers.

Chiaramonte, L., and B. Casu. 2013. The determinants of bank CDS spreads: evidence from the financial crisis. The European Journal of Finance 19: 861-887.

Coles, J., N. Daniel, and L. Naveen. 2006. Managerial incentives and risk-taking. Journal of Financial Economics 79 (2): 431-468.

Corrado, C. 2009. Why we have always used the Black-Scholes-Merton option pricing formula. Social Science Research Network (http:/www.ssrn.com).

Core, J., and W. Guay. 2002. Estimating the value of employee stock option portfolios and their sensitivities to price and volatility. Journal of Accounting Research 40 (3): 613-630.

Devers, C., G. McNamara, R. Wiseman, and M. Arrfelt. 2008. Moving closer to the action: examining compensation design effects on firm risk. Organization Science 19 (4): 548-566. 
Duong, L., and J. Evans. 2015. CFO compensation: evidence from Australia. Behavioural Finance and Recent Developments in Capital Markets 35: 425-443.

Edmans, A., and Q. Liu. 2010. Inside debt. Reviere of Finance: 1-28.

Hammami, Y., and A. Boubaker. 2015. Ownership structure and bank risk-taking: Empirical evidence from the Middle East and North Africa. International Business Research 8 (5).

Holmstrom, B. 1979. Moral hazard and observability. Bell Journal of Economics 10 (1): 74-91.

Hull, J., M. Predescu, and A. White. 2004. The relationship between credit default swap spread, bond yields, and credit rating announcements. Journal of Banking and Finance 28 (11): 27892811.

Jensen, M. C., and W. Meckling. 1976. Theory of the firm: Managerial behaviour, agency costs, and ownership structure. Journal of Financial Economics 3 (4): 305-360.

Jiang, J., K. R. Petroni, and I. Y. Wang. 2010. CFOs and CEOs: Who have the most influence on earnings management? Journal of Financial Economics 96: 513-526.

Laeven, L., and R. Levine. 2009. Bank governance, regulation and risk-taking. Journal of Financial Economics 93: 259-275.

Léautier, T. 2007. Corporate Risk Management for Value Creation: A Guide to Real-Life Applications ( $\left.1^{\text {st }} \mathrm{ed}\right)$. Risk Books. London, The United Kingdom.

Longstaff, F. A., S. Mithal, and E. Neis. 2005. Corporate yield spread: default risk or liquidity? New evidence from the credit-default swap market. Journal of Finance 60 (5): 2213-2253.

Myers, S. C., and N. S. Majluf. 1984. Corporate financing and investment decisions when firms have information that investors do not have. Journal of Financial Economics 13 (2): 187-221.

Paligorova. 2010. Corporate risk-taking and ownership structure. Bank of Canada Working Paper.

Pires, P., J. Pereira, and L. Martins. 2015. The empirical determinants of credit default swap spreads: a quantile regression approach. European Financial Management 21 (3): 556-589.

Securities and Exchange Commission. 2006. Final Rule: Executive Compensation and Related Person Disclosure. Release No. 33-8732a. File No. s7-03-06.

Tung, F., and X. Wang. 2011. Bank CEOs, inside debt compensation and the global financial crisis. Boston University School of Law Working Paper 11-49.

Vallascas, F., and K. Keasey. 2013. Does bank default risk increase with information asymmetry? Evidence from Europe. Social Science Research Network. (http:/www.ssrn.com).

Wei, C., and D. Yermack. 2011. Deferred compensation, risk, and company value: Investor reaction to CEO incentives. Review of Financial Studies.

White, R. 2014. The pricing and risk management of credit default swaps, with a focus on the ISDA model. Open Gamma Quantitative Research 16.

Wintoki, M.B., J. S. Linck, and J. M. Netter. 2012. Endogeneity and the dynamics of internal corporate governance. Journal of Financial Economics 105: 581-606. 